\title{
RUY BELO: GÉNIO E SUBLIME NA POESIA PORTUGUESA CONTEMPORÂNEA
}

\author{
RUY BELO: GENIUS AND SUBLIME IN CONTEMPORARY \\ PORTUGUESE POETRY
}

LUÍS ADRIANO CARLOS

Universidade do Porto

Recibido: 26/06/2019 Aceptado: 23/09/2019

\section{RESUMO / RESUMEN}

O poeta português Ruy Belo (1933-1978) publicou a sua obra nas décadas de 1960 e 1970. Viveu em Madrid entre 1971 e 1977, exercendo funções docentes na Universidade Complutense. Um dos seus mais conhecidos e celebrados poemas é uma meditação transcendente a propósito do encontro de Garcilaso de la Vega com Dona Isabel Freire. Doutorado em Direito Canónico, em Roma, com uma tese sob o tema "Ficção Literária e Censura Eclesiástica", viveria uma crise religiosa no início da década de 1960 que se repercute em toda sua poesia, vinda a público desde então e considerada entre as mais importantes do século XX em Portugal. O presente estudo visa determinar os aspectos essenciais que conferem à sua poesia uma dimensão maior, de grande poder estético e emotivo, mediante a unificação das teorias do Génio e do Sublime, que se integram intimamente nos seus versos poderosos de pendor versicular e que provêm das origens do próprio pensamento poetológico ocidental.

Palavras chave / Palabras clave: Estética Literária; Génio e Melancolia; Génio e Sublime; Poesia e Transcendência; Ritmo, Verso livre e Versículo. 


\section{ABSTRACT}

The Portuguese poet Ruy Belo (1933-1978) published his work in the 1960s and 1970s. He lived in Madrid between 1971 and 1977, teaching at the Complutense University. One of his best known and celebrated poems is a transcendent meditation on the meeting of Garcilaso de la Vega with Dona Isabel Freire. He has a doctorate in Canon Law in Rome, with a thesis on "Literary Fiction and Ecclesiastical Censorship", and lived through a religious crisis at the beginning of the 1960s that had repercussions on all his poetry, which has been published since then and is considered one of the most important of the 20th century in Portugal. This study aims to determine the essential aspects that give his poetry a greater dimension, of great aesthetic and emotional power, through the unification of the theories of the Genius and the Sublime, which are closely integrated in his powerful verses with a versicular slant and which come from the origins of Western poetic thought itself.

Keywords: Literary Aesthetics; Genius and Melancholy; Genius and Sublime; Poetry and Transcendence; Rhythm, Free Verse and Versicle.

Situando no centro dos Estudos Literários o tema da Criação, inerente à Poética desde as suas fundações originais, proponho-me defender uma tese segundo a qual Ruy Belo foi o poeta português contemporâneo que sintetizou ao mais alto nível o impulso criador, quando a vertiginosa aventura da Modernidade iniciada com o Romantismo parecia atingir um estado de exaustão ${ }^{1}$.

O tema da criatividade literária, artística e científica está omnipresente no movimento geral da cultura, marcado pela separação do conhecimento, como observa Giorgio Agamben, "entre um pólo extáctico-inspirado e um pólo racional-consciente, sem que nenhum dos dois jamais venha a eliminar completamente o outro"2. Neste longo debate, que já leva dois milénios e meio, os conceitos de génio e sublime, símbolos e arquétipos da Modernidade estética, em oposição à regra e ao belo ideal, gozam de uma relevância privilegiada, uma

1 Nascido e falecido em Portugal (1933-1978), Ruy Belo licenciou-se em Direito e em Filologia Românica na Universidade de Lisboa, tendo realizado entre as duas licenciaturas um doutoramento em Direito Canónico com a dissertação Ficção Literária e Censura Eclesiástica (Pontificium Athenaeum Angelicum, Facultas Iuris Canonici, Roma, 1958). No início dos anos 1960, abandonou o Opus Dei e começou a publicar a sua poesia com o livro Aquele Grande Rio Eufrates, de 1961. Entre 1971 e 1977, exerceu funções de Leitor de Português na Universidade Complutense de Madrid.

2 Giorgio Agamben, Stanze (Paris: Rivages, 1998), 10-11. 
vez que constituíram, no século XVIII, os principais instrumentos da resposta dos "modernos" à derrocada do edifício clássico.

Ora, a poesia de Ruy Belo, culminação e síntese, nas décadas de 1960 e 1970, do processo modernista português iniciado pela geração de Fernando Pessoa em 1915, convida a unificar as teorias do génio e do sublime, sem as quais não será possível compreender a potência criadora e a natureza singular da sua poética no quadro da Modernidade. Porém, estas duas teorias não estão livres de alguns obstáculos doutrinários. Se o sublime não oferece dificuldades de maior à sua compreensão crítica, embora muitas vezes seja confundido com as noções de grandiloquência, pompa e majestade, já o conceito de génio é fonte de incontáveis mal-entendidos, aparecendo não raro associado às ideias de fama, glória, excepcionalidade moral e mesmo patologia mental, quando não é reduzido a uma mera ficção romântica ${ }^{3}$.

Desde logo, Ruy Belo aglutina as duas grandes concepções do génio legadas pela Antiguidade, como que replicando a síntese de Marsilio Ficino no tratado De Vita, de 1489, ao harmonizar a tradição platónica do furor divino e da inspiração com a tradição aristotélica e fisiológica da melancolia. A força sobrenatural do entusiasmo, que etimologicamente significa "trazer um deus dentro de si”, estabelece sinergias inauditas com a disposição natural do humor melancólico ligeiramente inflamado ${ }^{4}$. Esta síntese teria no entanto um desenvolvimento polémico até à génese do Romantismo, de que foi uma das armas contra a preceptística horaciana dos clássicos, na medida em que, como bem cedo anunciaria Joseph Addison, num breve ensaio sobre o tema do génio em 1711, no n. ${ }^{\circ} 160$ do jornal The Spectator, existem dois tipos de personalidades geniais: os de segunda classe, que imitam modelos e autores, formados pelas regras e submetendo o talento natural aos ditames da arte polida, conveniente e correcta; e os de primeira classe, que imitam a natureza e são

3 Sobre a ideia de degenerescência e nevrose epileptóide dos poetas e artistas promovida pela Psicologia experimental e positivista no século XIX, são de destacar, desde 1820, os trabalhos de JeanÉtienne Esquirol, Bénédict Morel, Moreau de Tours, Cesare Lombroso, Francis Galton, J. F. Nisbet, William Hirsch e, num plano de divulgação com efeitos massivos sobre os intelectuais decadentistas e simbolistas do fim do século, Max Nordau. Ver: Giovanni Bovio, El Genio (Barcelona: Henrich, 1910); Luís Adriano Carlos, "Um Génio que não Era um Santo", Introdução a Ensaios Camilianos, por Óscar Lopes (Porto: Fundação Eng. António de Almeida, 2007), 12-13; Penelope Murray, ed., Genius: The History of an Idea (Oxford: Blackwell, 1989).

4 O intenso debate travado no século XVI em torno desta questão está profusamente documentado na monumental obra de Noel L. Brann, The Debate over the Origin of Genius during the Italian Renaissance (Leiden: Brill, 2002). 
movidos por um "fogo natural" para "vastas concepções das coisas e nobres excursões da imaginação"s.

Com efeito, na sua evolução tumultuosa e contraditória, o Romantismo nem sempre conseguiu produzir génios de primeira classe. Nos vários países europeus, o novo movimento, ao longo do século XIX, esvaiu-se num sentimentalismo convencional que vulgarizou o culto do génio enquanto categoria estética e poética, dissolvida no simples biografismo antropológico. $\mathrm{O}$ culto do génio transformou-se no culto do autor, praticado não só pela crítica mas também pela nascente história literária. O impacto da Psicologia experimental, da ideologia científica da degenerescência hereditária e do surto dos intelectuais como portadores do conhecimento positivo descredibilizou o conceito artístico de génio, a ponto de os múltiplos modernismos da "Belle Époque", frutos românticos por excelência, terem aberto uma profunda crise da retórica da sinceridade e criado um novo tipo de culto: o da impessoalidade da emoção estética, com T. S. Eliot, ou o do fingimento anticonfessional, com Fernando Pessoa, para me cingir a dois dos exemplos mais representativos.

Também Ruy Belo sentiu os efeitos do descrédito do génio romântico. É conhecido o belíssimo poema endereçado a Herberto Helder, "Vat 69", do livro Homem de Palavra[s], de 1970, cujo título joga a um tempo com a data de composição, a marca de whisky e a figura poética e profética do Vate. De facto, Ruy Belo desenvolveu uma faceta muito crítica em relação ao tema do génio, a favor da arte e da sua aprendizagem, documentada em vários textos. Por exemplo, no ensaio "Poesia Nova", de 1961: "O antigo vate romântico caiu em desgraça, passou de moda. Já lá vai o tempo em que esse demiurgo era honrado por possuir o fogo poético" ". Num artigo de 1969, era ainda mais preciso, com uma nota significativa que relegava o tópico teológico da inspiração para uma esfera fisiológica: "Podemos saber qual é o maior poeta, embora todo o poeta importe, desde que o seja. Mas o génio, o senhor da inspiração — inspiração é apenas o acto de encher o peito de ar — , para o qual tudo seriam facilidades [...], não, em boa verdade não sabemos o que seja"7. Por fim, em 1976, comentando a poesia de Nuno Guimarães, qualificava a inspiração como "conceito fatal e pernicioso"

Estas declarações foram reforçadas por algumas referências explícitas ao labor limae horaciano, especialmente nos versos autobiográficos de "Cólofon ou

\footnotetext{
5 Joseph Addison, The Spectator, 1 (Londres: Everyman's Library, 1907), 283-285.

6 Ruy Belo, Na Senda da Poesia (Lisboa: Assírio \& Alvim, 2002), 84.

7 Belo, "Da Espontaneidade em Poesia", em Na Senda, 108.

8 Belo, "Nuno Guimarães, Pastor da Palavra", em Na Senda, 334.
} 
Epitáfio", em que o poeta se autodescreve ocupado a "polir o seu poema", e no prefácio à 2. edição do mesmo livro Homem de Palavra[s], onde atribui especial importância ao "trabalho de limar, emendar, corrigir, até conquistar a naturalidade, se possível a simplicidade, que são uma conquista e não um dado gratuito dos deuses"9. Não obstante, em lugar nenhum assistimos à apologia de princípios externos e abstractos de composição, as famosas regras racionalistas e normativas. $\mathrm{O}$ que perpassa continuamente no seu discurso é uma adesão incondicional à ideia de autonomia do poema enquanto objectivação da subjectividade original do poeta: "é o poema que interessa", afirmou, por exemplo, no artigo "Poesia e Educação", de $1968^{10}$.

Todavia, o problema está longe de se esgotar nesta ordem de argumentos. Numa leitura sistemática dos seus textos críticos, encontramos uma constante dialéctica concentrada num esforço de síntese teórica do génio e da regra, do ingenium e da industria, da physis e da techné. O que Ruy Belo de facto contesta é o génio romântico, numa recusa geral do platonismo que não é estranha à sua crise religiosa. De resto, privilegia sistematicamente uma ideia de singularidade natural do acto poético. Não faltam referências ao "génio" inovador, às "musas" como metáforas quotidianas da vitalidade produtiva ${ }^{11}$, ao "dom poético" $12 \mathrm{e}$ ao "dom inato" 13 da criação. Por exemplo, no mesmo ensaio "Poesia Nova": "o poeta moderno, ao contrário dos clássicos, não despreza a inspiração"14. Ou no importante artigo "Musa Própria e Alheia": "Sem querermos tomar partido em antigas querelas, não há dúvida que a poesia se configura em alto grau como um dom inato, embora peça necessariamente um exercício que não consentirá ao poeta poisar a cabeça seja onde for ao longo da sua vida" ${ }^{15}$. Ou ainda, no mesmo artigo "Poesia e Educação": "[...] as novas gerações, talvez como reacção contra a crítica ou contra uma certa poesia, falam muito de 'ofício', de 'profissionalização', de 'artesanato'. Mas é claro que isso pressupõe qualidades inatas" 16.

"Musa Própria e Alheia" oferece-nos aliás uma desassombrada apologia do talento individual, no sentido de T. S. Eliot, reconhecendo que o ingenium e a industria, longe de se excluírem, pressupõem uma integração íntima, só possível 245,362 .

9 Ruy Belo, Homem de Palavra[s], em Todos os Poemas-I (Lisboa: Assírio \& Alvim, 2004),

10 Belo, Na Senda, 102.

11 Ruy Belo, "Entrevista 1" (1960), em Na Senda, 22.

12 Ruy Belo, "Advertência" (1969), em Na Senda, 11.

13 Ruy Belo, "Musa Própria e Alheia" (1962), em Na Senda, 55.

14 Belo, "Musa", 86.

15 Belo, "Musa", 55.

16 Belo, "Musa", 102-103. 
nos poetas dotados de faculdades essenciais como a temperatura e a intensidade: "A adopção de cânones — declara o autor —, a não ser na obra daqueles que os criaram ou com eles se fundiram a alta temperatura, jamais conseguiu encobrir a ausência de fogo interior, por um lado, e de intensidade de expressão, por outro"17. Os "autênticos poetas", acrescenta, são aqueles que "só a uma norma íntima obedecem", irradiando o "resplendor que sempre envolve e acompanha uma voz própria e pessoal", fonte da "irresistibilidade de uma expressão"18. Num outro artigo de 1962, "Poesia e Literatura", torna-se ainda mais explícita a valorização da natureza, não a natureza ideal mas uma natura naturans dotada do poder activo da criação: "O poeta, embora culto e senhor da sua técnica, parte da realidade ou — como disseram os clássicos e nós podemos voltar a dizer - imita a natureza. O literato parte quase sempre de um ou vários livros, é imitador de uma imitação. Daí provém a palidez das suas palavras, a pouca convicção e a arbitrariedade de tudo quanto diz" $"$.

Fica assim autorizada a minha perspectiva quanto às concepções perfilhadas por Ruy Belo acerca da criação. Com forte evidência, o poeta não tardou a adquirir uma percepção nítida (e angustiada) dos malefícios que podem resultar de um entendimento tecnocrático da criação. No prefácio de 1972 à 2. edição de Aquele Grande Rio Eufrates, reconhece ter perdido "uma certa ciência do abandono" com a aquisição progressiva da habilidade técnica, deixando no ar o sentimento de uma contradição teórica, que a praxis da sua poesia tão orgânica resolve por meio da integração de irregularidades e imperfeições como potências naturais do fenómeno criador: "Para um poeta que, quanto à concepção do poema, perfilha a doutrina designadamente de Horácio e de Sá de Miranda, dois eternos autores de vanguarda, para um poeta que portanto só publica textos que, por os haver longamente limado, tem por definitivos, não pode deixar de ser mau sinal ver-se na obrigação de, num caso ou noutro, proceder a alterações. Mas talvez lhe possa servir de consolação a ideia de que a perfeição é coisa de mortos" ${ }^{20}$.

Recorde-se, a propósito, que Horácio não elege apenas o “demorado trabalho da lima". Utiliza também as metáforas da "pedra de amolar", do "arranjar das unhas" e do "frisar da barba" ${ }^{21}$, recomendações que estão na origem da poesia polida, geralmente medíocre, a que aludia Addison na sua defesa do génio de primeira classe. Com formação jurídica e teológica, Ruy Belo

17 Belo, "Musa", 55.

18 Belo, "Musa", 54, 56.

19 Belo, "Musa", 60.

20 Ruy Belo, Todos os Poemas-I, 19-20.

21 Horácio, Arte Poética (Mem Martins: Inquérito, 2001), 89, 91. 
não ignorava que as leis e as regras são vontades isentas de paixão, como diria o Aristóteles da Política. Nem desconhecia, decerto, que a ideia do poeta engenheiro, proclamada por Edgar Allan Poe, caminha em sentido contrário ao do único poeta engenheiro da sua família, o apaixonado Álvaro de Campos que Pessoa criou como resposta ao estoicismo apático do horaciano Ricardo Reis. Não surpreende pois que o instinto poético de Ruy Belo procure na experiência do kairós o quid medium entre a arte e a natureza da poesia, que a estética da Modernidade descobriu no sublime de Pseudo-Longino.

A sua obra manifesta, com transparência, uma poderosa harmonia da componente artística do sublime, a fabricação das figuras e a nobreza da expressão, com a sua componente natural e primacial, a faculdade de elevação do pensamento e a intensidade da emoção criadora de entusiasmo, que representam, na fórmula de Longino, "o eco da grandeza interior" sem a qual não é possível a composição digna e elevada ${ }^{22}$. Poemas como $A$ Margem $d a$ Alegria (1974) ou "Ao Regressar episodicamente a Espanha, em Agosto de 1534, Garcilaso de la Vega Tem Conhecimento da Morte de Dona Isabel Freire", de Toda a Terra (1976), são exemplos notáveis da genialidade sublime, revelando, por entre imagens de extrema penetração emotiva, uma força apaixonada do estilo que muito deve a negligências formais criadoras de sensações orgânicas, efeitos que Longino considerou as fontes da simplicidade natural e da grandeza de expressão, acima da vigilância técnica confinada à pequenez da minúcia. Neste sentido, os poemas de Ruy Belo conservam os vestígios vivos do kairós, a ocasião apaixonada que lhes deu o ser - ou as ocasiões sucessivas, mescladas na síntese final - graças à energia do tónus anímico que lhes confere a tensão de uma anástase sem aparência de esforço e oferece uma sensação de natureza, como se a arte tivesse deixado de existir.

Estamos agora em condições de perceber que um dos aspectos exaltantes desta poesia provém da tradição do génio natural e do sublime, a tradição de Aristóteles e Longino, de que o século XVIII se serviu para elaborar uma estética da energia e da intensidade, sobretudo com Du Bos, Diderot, Burke, Duff, Gerard e Kant. Mesmo sem conhecer a totalidade deste complexo doutrinário, ainda hoje obscuro nos Estudos Literários, Ruy Belo realiza, no plano concreto dos poemas, a utopia de um sujeito esteticamente emancipado que regressa à região sensível das palavras e dos seus ritmos vitais, postulada pela Modernidade mas diluída no seu curso evolutivo, embora poetas como Whitman, Álvaro de Campos e Allen Ginsberg, por exemplo, nos tenham legado

22 Dionísio Longino, Do Sublime (Coimbra: Imprensa da Universidade de Coimbra, 2015), 48, 50 . 
uma experiência viva desse empirismo poético da imaginação. O génio natural da poesia, extremamente sensível nos versos de Ruy Belo, é "o princípio vital que anima todas as espécies de composição", como esclareceu William Duff num ensaio de $1767^{23}$. O saber técnico é seu agente ancilar, uma infra-estrutura subordinada ao seu poder produtivo, não sobrenatural mas superestrutural, aspecto determinante para compreendermos a questão da causalidade genial.

Se adaptarmos as categorias causais de Aristóteles a esta reflexão, podemos estabelecer a existência de quatro causas primeiras na génese do poema: a formal, a material, a eficiente e a final. Ora, o génio está longe de ser uma causa formal, pois esta consiste nas regras de composição e agenciamento. Também não é uma causa material, composta pelos materiais que constituem o poema nos planos da expressão e do conteúdo, a linguagem e a lexis, textos assimilados por leituras, circunstâncias e motivos, representações temáticas e simbólicas. Não é ainda uma causa final, a razão e o fim que fizeram nascer a necessidade do poema, geralmente a comunicação estética. Bem entendido, o génio é uma causa eficiente, o princípio do movimento, a força motriz que agencia a passagem do possível à realidade, dando-lhe forma própria e assim satisfazendo o telos. Como assinalava Aristóteles, a madeira não tem o poder de fabricar a cama, nem o bronze pode engendrar a estátua, porque a madeira e o bronze são meras causas materiais. Nem tão-pouco os saberes técnicos do carpinteiro e do escultor conseguem criar só por si os dois objectos, tal como a necessidade que os solicita. Nem, já agora, o dicionário e a gramática em relação ao poema.

O génio é portanto o impulso criador, o princípio da mudança e a causa eficiente, que adiciona matéria ao nada inicial. Mas ele não se limita a criar o poema. Ele engendra as suas criações de uma forma peculiar e distinta, sem a qual não poderíamos distinguir o poeta e o poetastro ou a criação original e o fabrico em série. Isto não significa que se trate do autor pessoal e civil, considerado na sua vida prática e trivial, ou mesmo ruminando quotidianamente os projectos e as ideias, também ele uma das causas materiais do poema. Tratase desse mesmo autor enquanto ser transfigurado pelo entusiasmo do kairós e, nessa medida, trata-se já de um outro ser, num outro nível de consciência e potencialidade, extensão criadora do homem e enteléquia do poema, elevado ao "grau supremo da síntese", vivendo intensamente "a mais pura compenetração que a natureza pode fazer de si mesma" ${ }^{24}$.

23 William Duff, An Essay on Original Genius (Delmar: Scholars' Facsimiles \& Reprints, 1978), 25.

24 Bovio, El Genio, 62, 74. 
O génio acaba por sintetizar todas as outras causas do poema, que nada seriam sem o sopro da sua actividade formadora. Ruy Belo ostenta entretanto uma outra característica, que só encontramos nos autores de excepção: a síntese de todas as faculdades intelectuais, num alto grau de conexão mútua e fusão natural. Sensações, memória, entendimento e gosto são sujeitos a uma íntima integração com a faculdade criadora por excelência, a imaginação, gerando uma natureza fértil e penetrante que se sobrepõe à arte, em virtude do seu poder de associação de diferentes percepções, característica que confere um vigor peculiar ao génio, tal como explicou Alexander Gerard, em 1774, no seu ensaio fundamental sobre o tema ${ }^{25}$. Ruy Belo exibe este vigor de forma aparentemente natural na generalidade dos seus versos. É porém impossível citar e reproduzir aqui os melhores exemplos, dada a grande extensão dos poemas. A Margem da Alegria, cuja leitura se prolongaria por não menos de duas horas (compõe-se de 2168 versos), é um exemplo prodigioso de poder associativo e sublimidade. Outros poemas recomendáveis seriam, por exemplo, "Vat 69", de Homem de Palavra[s], "Elogio de Maria Teresa", de Transporte no Tempo (1973), "Em louvor do Vento", "Muriel" e "Ao Regressar Episodicamente a Espanha, em Agosto de 1534, Garcilaso de la Vega Tem Conhecimento da Morte de Dona Isabel Freire", de Toda a Terra. Sem embargo, vejamos, do livro Homem de Palavra[s], a bela composição "Oh as Casas as Casas as Casas", de extensão relativamente breve:

$\mathrm{Oh}$ as casas as casas as casas

as casas nascem vivem e morrem

Enquanto vivas distinguem-se umas das outras

distinguem-se designadamente pelo cheiro

variam até de sala pra sala

As casas que eu fazia em pequeno

onde estarei eu hoje em pequeno?

Onde estarei aliás eu dos versos daqui a pouco?

Terei eu casa onde reter tudo isto ou serei sempre somente esta instabilidade?

As casas essas parecem estáveis mas são tão frágeis as pobres casas

Oh as casas as casas as casas

mudas testemunhas da vida

elas morrem não só ao ser demolidas

elas morrem com a morte das pessoas

As casas de fora olham-nos pelas janelas

25 Alexander Gerard, An Essay on Genius (Munique: Wilhelm Fink Verlag, 1966), 7, 27. 
Não sabem nada de casas os construtores

os senhorios os procuradores

Os ricos vivem nos seus palácios

mas a casa dos pobres é todo o mundo

os pobres sim têm o conhecimento das casas

os pobres esses conhecem tudo

Eu amei as casas os recantos das casas

Visitei casas apalpei casas

Só as casas explicam que exista

uma palavra como intimidade

Sem casas não haveria ruas

as ruas onde passamos pelos outros

mas passamos principalmente por nós

$\mathrm{Na}$ casa nasci e hei-de morrer

na casa sofri convivi amei

na casa atravessei as estações

respirei - ó vida simples problema de respiração

$\mathrm{Oh}$ as casas as casas as casas ${ }^{26}$

Ao contrário do que sucede com as tendências clássicas e românticas, o poeta não dissocia a razão e a imaginação. O entendimento preciso das relações de causalidade alia-se a uma imaginação que, longe de se limitar a reproduzir percepções armazenadas na memória, "as exibe como existências independentes produzidas por ela" ${ }^{27}$, conferindo-lhes uma nota original intensificada por um registo familiar regressivo, expressão estilística de uma esfera de intimidade sublime. Este ponto é nuclear, pois o segredo de Ruy Belo reside no recurso às faculdades intelectuais não imaginativas como termostatos da imaginação. Por isso, o seu génio característico, patente neste poema, é da ordem da simplicidade inesperada, longe do génio extravagante naufragando em ondas de loucura ou do literato cristalizando num racionalismo estéril. As faculdades da percepção, da memória e do entendimento, assistidas pelo gosto, garantem a nitidez sensorial e intelectual da imaginação meditativa, que por sua vez lhes transmite colorido e vivacidade.

Uma outra causa eficiente provém dos poderes de invenção e execução, interligados numa convergência simultânea, durante o kairós, das principais fases retóricas da elaboração, a inventio, a dispositio e a elocutio. Os pensamentos parecem ser descobertos e verbalizados no próprio processo da sua

26 Belo, Todos os Poemas-I, 289, 290.

27 Gerard, An Essay, 29. 
ordenação, assim contribuindo para o efeito raro e difícil de uma simplicidade natural, em versos longos e poemas extensos de grande complexidade. $\mathrm{O}$ caso mais representativo é ainda $A$ Margem da Alegria, cuja composição exigiu uma longa fase de descoberta, em torno do mito histórico de Pedro e Inês ${ }^{28}$. E, no entanto, o poema é percebido como natureza animada por um sopro anímico que lhe confere uma vitalidade excepcional. A experiência da sua leitura faz sentir vivamente aquela facilidade natural de que falava Du Bos a propósito do génio ${ }^{29}$.

Podemos pois assumir que a vida do poema é um "simples problema de respiração", em virtude do primado do ritmo sobre o metro como princípio do movimento organizativo, outro dos factores que possibilitam a génese orgânica do génio natural e que criam as melhores condições para confirmar a proposição de Kant, na "Analítica do Sublime": "Génio é a inata disposição do ânimo (ingenium), pela qual a natureza dá a regra à arte" ${ }^{30}$. Aqui não existe contradição entre a techné e a physis, porque a arte é produção por meio de liberdade, através da qual realiza a síntese do sujeito e da natureza. Subentende-se que o génio artístico detém os poderes da originalidade e da exemplaridade, desconhecendo a regra no acto da criação mas fornecendo-a como exemplo através da sua arte, e não por meio da ciência, o que explica a dificuldade dos críticos em compreender os poetas que reúnem condições excepcionais, empobrecendo muitas vezes a natureza das obras com a projecção dos mesmos conceitos que aplicam às produções menores. Ruy Belo reúne essas condições ao produzir ideias estéticas, poeticamente objectivadas, que traduzem a natureza viva do sujeito e são por isso de difícil captação sob regras e conceitos.

A originalidade e a exemplaridade são contudo naturezas sujeitas às leis do tempo. Dizia Ruy Belo, nos primórdios da sua carreira literária, que "o verso perde temperatura e rigor" 31 com a repetição dos mesmos processos. É uma verdade que a história da literatura está habituada a confirmar. Mas o interessante desta afirmação reside no motivo da "temperatura", um conceito físico e termodinâmico associado à energia, que não integra as categorias da Poética e das disciplinas conexas. Mesmo assim, Ruy Belo utilizou este termo como categoria de apreciação da qualidade estética de obras literárias, além de ter consubstanciado o conceito na matéria sensível da sua poesia,

28 Sobre este assunto, é imprescindível a demonstração exaustiva de Ana Maria Soares nos dois volumes da sua dissertação de doutoramento, "A Alegria e o Mal em Ruy Belo: Estudo da Composição Hipertextual d'A Margem da Alegria", Universidade do Porto, 2017.

29 Jean-Baptiste Du Bos, Réflexions Critiques sur la Poësie et sur la Peinture (Genebra: Slatkine, 1993), 142 e toda a 1. ${ }^{a}$ Secção da 2. Parte, "Du Génie en général".

30 Immanuel Kant, Crítica da Faculdade do Juizo (Lisboa: Imprensa Nacional-Casa da Moeda, 1998), 211.

31 Ruy Belo, "Poesia e Literatura", em Na Senda, 60. 
reconhecidamente calorosa e calorífica. Mais tarde, referiu-se à necessidade de a "temperatura da expressão" ser "elevada", como "única forma de vigorar para além do momento que passa" 32 . Trata-se, como há pouco se observou, de uma metáfora tradicional associada às descrições do estado de genialidade sob as formas do "fogo" e do "entusiasmo", que o empirista Alexander Gerard, o mais consistente teorizador do génio, definiu como "elevação e calor da imaginação" "33, de que o poder associativo retira o vigor e a vivacidade. Segundo Kant, leitor atento de Gerard, o entusiasmo "parece ser a tal ponto sublime", pela "tensão das forças mediante ideias que dão ímpeto ao ânimo", que "sem ele nada de grande pode ser feito" 34 .

Se agora relermos a Poética de Aristóteles, à margem das simplificações de Scaliger e dos horacianos, constataremos que o Estagirita está longe de reduzir a poesia à mera techné, prevendo mesmo a sua integração com o entusiasmo irracional. No capítulo 17, podemos ler que "a arte poética pertence aos seres bem dotados ou levados ao delírio"35. No capítulo 22, o autor afirma que "o mais importante de tudo é saber fazer as metáforas, porque isso não se aprende nos demais e é o signo de uma natureza bem dotada" ${ }^{36}$. Se consultarmos a Retórica, deparamos com a mesma ideia: "É sobretudo a metáfora que possui clareza, agradabilidade e exotismo, e ela não pode ser extraída de qualquer outro autor" ${ }^{37}$. Finalmente, somos surpreendidos por esta fórmula, que não consta dos manuais de Poética: "a poesia é algo que provém da inspiração" 38 . Resumindo: se a propriedade mais importante da poesia não pode ser racionalmente reproduzida, o poder que a produz não é susceptível de ser traduzido por regras.

A intuição beliana da "temperatura" como causa da criação original é confirmada num outro texto de Aristóteles, o fecundo Problema $X X X$, 1, que apresenta uma explicação da genialidade dos peritoi ou seres excepcionais pela acção do humor melancólico, a bílis negra. O autor centra-se na natureza fisiológica da disposição criadora, no ethos do poeta e no kairós, com o intuito de fazer comunicar o furor platónico e os meios da mimesis. Em harmonia com os ensinamentos hipocráticos, argumenta que os humores naturais - sangue, linfa, bílis amarela e bílis negra ou melancolia - detêm o poder de moldar o carácter e os temperamentos, tal como o vinho em situações momentâneas, por acção do calor e do pneuma, sopro subtil que refrigera o sistema orgânico. Ora,

\footnotetext{
32 Ruy Belo, "Poesia e Luta pelo Poder" (1972), em Na Senda, 311-312.

33 Gerard, An Essay, 67.

34 Kant, Crítica, 171.

35 Aristóteles, La Poétique (Paris: Seuil, 1980), 93 (55a).

36 Aristóteles, La Poétique, 117 (59a).

37 Aristóteles, Retórica (Lisboa: Imprensa Nacional-Casa da Moeda, 1998), 180 (1405a).

38 Aristóteles, Retórica, 191 (1408a).
} 
a melancolia é um humor frio e seco nos casos patológicos, gerador de distimias, medo, ansiedade e tristeza. Porém, a melancolia natural, existente nos homens que são melancólicos não por doença mas por natureza, consiste numa mistura de calor e frio, sendo portanto instável e variável. Quando a mistura é demasiado fria, engendra distimias e caracteres depressivos; quando aquece excessivamente, gera estados de euforia e loucura; mas, quando a temperatura é bem regulada, restabelecendo o equilíbrio pela acção refrigerante do pneuma, a melancolia desperta os seres dotados de um poder criador excepcional. É esta a ocasião propícia, o kairós, o momento de acesso a uma segunda natureza, que afinal corresponde, nos termos de Gerard e de Kant, ao bom equilíbro do frio entendimento e do calor da imaginação ${ }^{39}$.

Segundo Jackie Pigeaud, este texto introduz, pela primeira vez, o tema bem moderno da criatividade como pulsão que procura em nós uma segunda natureza, oculta na obscuridade da nossa fisiologia, à espera do kairós. Devido à sua natureza instável, a melancolia comporta o poder da etopoiese, da modelagem dos comportamentos e dos caracteres, pondo-nos em comunicação com o nosso thymos, lugar íntimo do Ser e das emoções, centro da dor e da alegria. Por outras palavras, a etopoiese procede à integração íntima da fisiologia e da retórica, pela translação do ethos através do tropo metafórico desencadeado pelo humor melancólico ${ }^{40}$. Nesta perspectiva, a poesia de Ruy Belo manifesta oscilações tímicas que explicam a mistura da tristeza e da alegria em gradações muito matizadas, permanentemente sob o efeito da pulsão etopoiética, e por isso jamais se fixando num lugar determinado. A distimia e a atimia, o mal de vivre, a angústia, o desespero, o desânimo, a pulsão da morte e o luto por si mesmo constituem os materiais volitivos da faceta mais negra e sublime dos seus versos.

Estranhamente, e este é um dos grandes efeitos de Ruy Belo, a temperatura nunca decresce quando o sistema bipolar faz descer o poeta até ao fundo da depressão existencial. A causa reside numa sabedoria da dosagem e da mistura dos humores, que aliás merece melancólica jubilação numa espécie de salmo, "A Mão no Arado", do livro O Problema da Habitação - Alguns Aspectos:

Feliz aquele que administra sabiamente a tristeza e aprende a reparti-la pelos dias Podem passar os meses e os anos nunca lhe faltará Oh! como é triste envelhecer à porta

39 Cf. Aristóteles, L'Homme de Génie et la Mélancolie: Problème XXX, 1 (Paris: Rivages, 1988).

40 Jackie Pigeaud, Prefácio a L'Homme de Génie et la Mélancolie, por Aristóteles (Paris: Rivages, 1988), 51-52. 
entretecer nas mãos um coração tardio

$\mathrm{Oh}$ ! como é triste arriscar em humanos regressos

o equilíbrio azul das extremas manhãs do verão

ao longo do mar transbordante de nós

no demorado adeus da nossa condição

É triste no jardim a solidão do sol

vê-lo desde o rumor e as casas da cidade

até uma vaga promessa de rio

e a pequenina vida que se concede às unhas

Mais triste é termos de nascer e morrer

e haver árvores ao fim da rua

É triste ir pela vida como quem

regressa e entrar humildemente por engano pela morte dentro

É triste no outono concluir

que era o verão a única estação

Passou o solidário vento e não o conhecemos

e não soubemos ir até ao fundo da verdura

como rios que sabem onde encontrar o mar

e com que pontes com que ruas com que gentes com que montes conviver através de palavras de uma água para sempre dita

Mas o mais triste é recordar os gestos de amanhã

Triste é comprar castanhas depois da tourada

entre o fumo e o domingo na tarde de novembro

e ter como futuro o asfalto e muita gente

e atrás a vida sem nenhuma infância

revendo tudo isto algum tempo depois

A tarde morre pelos dias fora

É muito triste andar por entre Deus ausente

Mas, ó poeta, administra a tristeza sabiamente ${ }^{41}$

Por estas razões "administrativas", a alegria, um dos tópicos emblemáticos da obra, nunca chega a corresponder ao seu valor lexical paradigmático, dado ser submetida a constantes efeitos do humor e do tropo, em oscilações bruscas que dois versos do mesmo livro, O Problema da Habitação, ilustram com simplicidade: primeiro, "a alegria é uma casa recém-construída"; algumas páginas depois, "a alegria é uma casa demolida" ${ }^{42}$. Na verdade, a alegria constitui

41 Belo, Todos os Poemas-I, 159-160.

42 "Quasi Flos" e "Imaginatio Locorum", em Belo, Todos os Poemas-I, 137, 144. 
uma metáfora à solta pela etopoiese instável e dinâmica do humor: ora "um coração tristemente contente" ${ }^{43}$, ora uma "alegria tão forte que causava dor", ora "essa margem que há antes da morte / ou só depois da morte"44. Por conseguinte, caracterizar Ruy Belo como poeta da alegria, sem mais, é correr o risco de o remeter para a emoção superficial e ridícula dos temperamentos sanguíneos, que riem de tudo e de nada a propósito de nada e de tudo, segundo a caracteriologia humorística. A menos que se pretenda inscrevê-lo no tópico da alegria mística, o que, não sendo desprovido de pertinência, é contudo redutor, porquanto a sua poesia exibe uma mescla de tonalidades altamente contrastada, que podemos traduzir pela mistura de sangue e melancolia, ou simplesmente pelo delight de Edmund Burke, essa fascinação tingida de terror que caracteriza o sentimento sublime $^{45}$. Sem dúvida, esta alegria pode simbolizar o fogo do entusiasmo e a força criadora, e afinal não é senão a alegria poética da criação durante o kairós, de que o poema é o registo, mas sempre com uma tintura de tristeza e um halo de tragédia, a "íntima tristeza subjacente à mais feroz das alegrias" de que fala o poeta no livro Toda a Terra ${ }^{46}$. Em suma, esta alegria é a alegria sombria da melancolia, que Victor Hugo, no romance Les Travailleus de la Mer, de 1866, sintetizou numa fórmula lapidar: La mélancolie, c'est le bonheur d'être triste.

Entretanto, a natureza de Ruy Belo não se confina à esfera antropológica e fisiológica. Ela é também uma cosmologia que regride em direcção à physis présocrática dos elementos orgânicos e das configurações rítmicas. Os títulos do primeiro e dos últimos livros, Aquele Grande Rio Eufrates, Toda a Terra e Despeço-me da Terra da Alegria (1977), simbolizam a recorrência obsidiante das substâncias primordiais na generalidade das composições. Embora não consista numa poesia elemental, à semelhança das facturas epigramáticas do imagismo metafórico, os elementos crescem de poema a poema como verdadeiras raizes, no sentido original de Empédocles, ou como "hormonas da imaginação" que desencadeiam todo um movimento de grupos de imagens em busca da expressão da "intimidade da matéria", na perspectiva de Gaston Bachelard ${ }^{47}$. $\mathrm{O}$ ar de Anaxímenes e o fogo de Heraclito constituem as metáforas

43 Aquele Grande Rio Eufrates, em Belo, Todos os Poemas-I, 130. 227,260 .

44 A Margem da Alegria, em Ruy Belo, Todos os Poemas-II (Lisboa: Assírio \& Alvim, 2004),

45 Edmund Burke, A Philosophical Enquiry into the Origin of Our Ideas of the Sublime and Beautiful (Oxford: Oxford University Press, 1998), 34, 47, 67, 122-123.

46 "O Tempo Sim o Tempo Porventura", em Ruy Belo, Todos os Poemas-III (Lisboa: Assírio \& Alvim, 2004), 157.

47 Gaston Bachelard, L'Air et les Songes (Paris: José Corti, 1992), 19, e La Terre et les Rêveries du Repos (Paris: José Corti, 1992), 2-3. 
privilegiadas da poética do génio e dos seus efeitos estéticos de alacridade sublime.

Por esse motivo, Ruy Belo é acima de tudo um poeta heraclitiano. O ritmo dos movimentos contraditórios da sua melancolia instável organiza-se não numa dialéctica hegeliana mas num fluxo perpétuo, anterior à ordem e ao número, isento do rigor mecânico das antíteses como as águas do rio Eufrates: "tenho no movimento o meu sustento", "sinto-me passar como a água corrente / como ela me mostro móvel e instável", escreve o autor em Toda a Terra ${ }^{48}$. No fundo, ele busca a unidade na discórdia - não a unidade na concórdia, à maneira pitagórica e platónica, mas a própria discórdia como verdade e unidade natural do Ser, que nem se unifica nem se fragmenta, perdido algures entre os dois estados, como que no vazio atómico de Demócrito. Daí que a etopoiese da sua melancolia participe de uma fluidez que nenhum sistema heteronímico pode satisfazer com a sua mecânica esquemática da alteridade. $O$ problema da habitação é este mesmo, a impossibilidade de repousar na própria mudança, como sugere o poema "Estudo" de Homem de Palavra[s]: "ser não outra coisa ser a própria mudança / ficar nesse mudar com a possível estabilidade / e isso no passado e não nestas manhãs que me consomem" 49 .

Este passado é o país da infância, onde toda a criança vive dentro da mudança e fala com as coisas como se elas fossem pessoas vivas. Um mundo que o poeta experimentou, naturalmente, na sua própria infância, mas que adquiriu um profundo sentido poético com a leitura da Scienza Nuova de Giambattista Vico. Podemos perceber o grau de influência desta obra setecentista no seu pensamento pela leitura dos ensaios, em particular "Poesia Nova", cujo título foi moldado no de Vico. Neles sobressaem alguns dos grandes princípios do filósofo italiano: o primado da palavra poética sobre a palavra prática e do verso sobre a prosa; a origem metafórica e afectiva da poesia; a faculdade poética como privilégio da infância; e a poesia como "exercício da sabedoria da linguagem", traduzida na "exploração intensiva da fala"

Nos termos de Vico, a "sabedoria da linguagem" é propriamente a sapienza poetica do tempo dos heróis, anterior à idade dos filósofos, portanto pré-lógica e pré-científica ${ }^{51}$. Emotiva e estética, ela radica numa metafísica substancial que

48 "Nem sequer não" e "Ao Regressar episodicamente a Espanha, em Agosto de 1534, Garcilaso de la Vega Tem Conhecimento da Morte de Dona Isabel Freire", em Belo, Todos os Poemas-III, 77, 150 .

49 Belo, Todos os Poemas-I, 304.

50 “Poesia, Último Reduto da Literatura?" (1972), em Belo, Na Senda, 317.

51 Giambattista Vico, Principes d'une Science Nouvelle Relative à la Nature Commune des Nations (Paris: Fayard, 2001), 32, 103, 157. 
dá sentido e paixão ao diálogo entre o corpo e a matéria vasta do universo, a terra, o mar e o céu. Não admira que Ruy Belo tenha aderido incondicionalmente a esta visão da história, que atribui aos heróis a condição de poetas naturais e sublimes, senhores de uma faculdade inata para a criação poética, de que os textos homéricos seriam a síntese suprema, ensinando-nos que "o trabalho mais sublime da poesia é dar sentimento e paixão às coisas privadas de sensibilidade" 52 . Assim, ainda segundo Vico, a infância do mundo é habitada pela memória e pela imaginação, pela força expressiva das imagens, pelo paroxismo da dor e da alegria. Eis o mundo da infância e da casa, da intimidade mais pura e absoluta, que impregna o transporte no tempo dos versos de Ruy Belo, celebrado aliás com intensidade afectiva na longa anáfora que introduz $A$ Margem da Alegria. Mais do que recordação espiritual ou anamnese platónica à maneira de Wordsworth, trata-se de uma vivência sensitiva a todo o instante experienciada pelo génio na palpitação genesíaca dos versos, mas irremediavelmente perdida com o último sopro do poema.

Em certo sentido, a poesia foi a verdadeira infância de Ruy Belo. Nela disseminou a natureza, a casa, as ruas, os campos, a humanidade e a sua nudez, a atmosfera e o ritmo que deu vida aos elementos. No país poético da infância, todas as coisas se rodeiam de pneuma, o princípio vital que insufla ressonância e vivacidade na matéria, concebido por Anaxímenes e Diógenes de Apolónia na descrição naturalista do alento do mundo, equivalente ao spiritus latino, ao ruah' hebreu, ao prâna hindu e ao qiyun da estética chinesa. O pneuma é o fundamento do tópico da respiração que irrompe recorrentemente, e em várias modalidades, nos versos projectivos de Ruy Belo, desde a simples metaforização físiológica do princípio vital, em conflito com a pulsão da morte, até à complexa meditação epidíctica sobre a função respiratória do corpo, da casa e do universo, de que o longo poema "Em louvor do Vento", de Toda a Terra, é o exemplo mais significativo, com uma atitude pneumática que estes três versos podem sintetizar em pequena escala: "Deve haver algures no meu corpo um lugar expressamente reservado para a voz do vento"; "Neste momento sou apenas sou pelo menos desde os pés da cama até aqui à cabeceira a voz vasta do vento"; "cresce o ritmo da minha respiração o pulso bate-me cada vez mais apressadamente" ${ }^{93}$. Ao compor esta ode profundamente respirada, com 122 versos que rondam uma média de trinta a quarenta sílabas, incluindo o mais longo de toda a sua poesia —o verso 20, de quarenta e cinco sílabas —, Ruy Belo deu expressão sensorial à ideia estética nuclear da sua poética: a ideia de uma poesia do pneuma contínuo

52 Vico, Principes, 99.

53 Belo, Todos os Poemas-III, 16. 
como causa eficiente, força motriz e energia rítmica na sua máxima síntese e compenetração.

A poesia é de facto um "simples problema de respiração", graças à infusão do ânimo na matéria da linguagem pelo pneuma contínuo que garante o alento e a coesão do verso e do poema, propensos à dispersão em virtude da grandeza extensiva que os atrai na economia geral da obra. Dificilmente Ruy Belo se teria tornado o grande mestre do versilibrismo e do poema longo, estatuto que a crítica em geral lhe reconhece, sem o princípio de coesão e o factor energético inerentes à natureza pneumática do ritmo e dos seus dispositivos paralelísticos (em especial, epanalepse, epanáfora, rima aliterante, paronomásia, poliptoto e homeoptoto). Para fazermos uma ideia da magnitude da empresa, os textos com mais de cem versos representam 55\% do total de 15.976 unidades versificatórias, mas correspondem apenas a $10 \%$ da totalidade dos 289 poemas. Face a estes dados, não é difícil concluir que Ruy Belo desafia, e acaba por vencer, o postulado de Edgar Allan Poe segundo o qual a intensidade poética só é possível no poema breve, um dos lugares-comuns da modernidade a partir do Simbolismo, e sobretudo entre os poetas da geração do autor de Boca Bilingue (1966).

Esta poética é pois muito dependente das configurações rítmicas, a ponto de nos proporcionar uma das mais felizes concretizações daquilo que Meschonnic designa por ritmo prosódico-semântico, um movimento subjectivo do discurso que afirma a historicidade singular do sujeito - não a sua fala ou a sua escrita, mas a sua oralidade, um tom peculiar e inconfundível, uma voz íntima e viva, uma pulsão, uma natureza literalmente poética. $\mathrm{O}$ ritmo de que falo, e que condensa a vis poetica de Ruy Belo, filia-se na ideia subjacente ao rithmós de Heraclito e Demócrito, tal como Benveniste o descreveu: um ritmo ainda puro do arithmós pitagórico que fundamenta a teoria rítmica de Platão, baseada nos critérios da ordem e da medida, fundadores do esquematismo rígido do sistema acentual canónico ${ }^{54}$. Em Ruy Belo, este sistema submete-se ao primeiro dos três meios da mimesis aristotélica, o ritmo ou fluxo das formas móveis e momentâneas que transmite a sensação viva de uma orgânica da linguagem, afectando sincreticamente os movimentos fónicos e semânticos do discurso e da harmonia.

Eis a natureza íntima da poesia resgatada por Ruy Belo: o ritmo como íman das palavras e das imagens, por meio do qual, nos termos de Octavio Paz, o

54 Émile Benveniste, "La Notion de 'Rythme' dans Son Expression Linguistique", em Problèmes de Linguistique Générale, 1 (Paris: Gallimard, 1981), 333-334. 
poeta encanta a linguagem ${ }^{55}$. E encantar a linguagem é encantar o leitor, que pela experiência estética da natureza rítmica dos pensamentos se resgata a si mesmo enquanto ser no mundo e para o mundo - não este mundo automatizado, mas o mundo realmente humano.

Génio e sublime são portanto fluidos rítmicos do espírito que animam e vitalizam a matéria na ordem das suas representações verbais. Pela íntima reconciliação da matéria e do espírito, desígnio primordial da poesia e da arte, Ruy Belo introduz no coração do sensível um eixo de transcendência que desperta o sentimento de uma faculdade supra-sensivel do ilimitado. Tal sentimento é o sentimento do sublime, de acordo com Kant, correspondente a uma força moral de resistência da imaginação que provoca na ordem finita da linguagem o estremecimento sagrado da comunhão íntima, mas fugitiva, do quotidiano e do infinito. É esta aliança do sublime e do familiar que dá a nota característica de Ruy Belo, através da oralidade afectiva da sua voz e de uma heurística sem repouso da intimidade obscura das coisas e dos seres. Não são raros os seus versos que geram comoção e estremecimento nos instantes privilegiados da leitura, em que o estranho e o familiar mal se distinguem um do outro. Nesses momentos, o génio de Ruy Belo encontra-se no apogeu das suas forças e no ápice do seu spiritus, exibindo o raro poder estético de elevação da intimidade geral a uma ordem do particular que pode ser partilhada por todos.

\section{REFERÊNCIAS BIBLIOGRÁFICAS}

Addison, Joseph. "The Spectator" 160 (1711). Em The Spectator, 1, editado por Gregory Smith. Londres: Everyman's Library, 1907.

Agamben, Giorgio. Stanze: Parole et Fantasme dans la Culture Occidentale. Paris: Rivages, 1998.

Aristóteles. La Poétique. Editado por Roselyne Dupont-Roc e Jean Lallot. Paris: Seuil, 1980.

—. L'Homme de Génie et la Mélancolie: Problème XXX, 1. Editado por Jackie Pigeaud. Paris: Rivages, 1988.

- Retórica. Editado por Manuel Alexandre Júnior, Paulo Farmhouse Alberto e Abel do Nascimento Pena. Lisboa: Imprensa Nacional-Casa da Moeda, 1998.

Bachelard, Gaston. La Terre et les Rêveries du Repos. Paris: José Corti, 1992. —. L'Air et les Songes. Paris: José Corti, 1992.

55 Octavio Paz, El Arco y la Lira (México: Fondo de Cultura Economica, 1981), 53, 56. 
Belo, Ruy. Na Senda da Poesia. Editado por Maria Jorge Vilar de Figueiredo. Lisboa: Assírio \& Alvim, 2002.

—. Todos os Poemas-I. Lisboa: Assírio \& Alvim, 2004.

-. Todos os Poemas-II. Lisboa: Assírio \& Alvim, 2004.

—. Todos os Poemas-III. Lisboa: Assírio \& Alvim, 2004.

Benveniste, Émile. "La Notion de 'Rythme' dans Son Expression Linguistique". Em Problèmes de Linguistique Générale, 1, 327-335. Paris: Gallimard, 1981. Bovio, Giovanni. El Genio: Un Capitulo de Psicología. Barcelona: Henrich, 1910.

Brann, Noel L. The Debate over the Origin of Genius during the Italian Renaissance: The Theories of Supernatural Frenzy and Natural Melancholy in Accord and in Conflict on the Threshold of the Scientific Revolution. Leiden: Brill, 2002.

Burke, Edmund. A Philosophical Enquiry into the Origin of Our Ideas of the Sublime and Beautiful. Oxford: Oxford University Press, 1998.

Carlos, Luís Adriano. “A Margem da Alegoria em Ruy Belo". Colóquio / Letras 155-156 (2000): 259-270.

—. "O Problema da Respiração". A Phala 86 (2001): 50-51.

-. "Um Génio que não Era um Santo". Introdução a Ensaios Camilianos, por Óscar Lopes, 5-14. Porto: Fundação Eng. António de Almeida, 2007.

Dessons, Gérard e Henri Meschonnic. Traité du Rythme: Des Vers et des Proses. Paris: Nathan, 2003.

Du Bos, Jean-Baptiste. Réflexions Critiques sur la Poësie et sur la Peinture. Reimpressão da edição de 1770. Genebra: Slatkine, 1993.

Duff, William. An Essay on Original Genius and Its Various Modes of Exertion in Philosophy and the Fine Arts, particularly in Poetry. Reimpressão da edição de 1767, por John L. Mahoney. Delmar: Scholars' Facsimiles \& Reprints, 1978.

Eliot, T. S. "A Tradição e o Talento Individual". Em Ensaios de Doutrina Crítica, editado por J. Monteiro-Grillo, 19-32. Lisboa: Guimarães Editores, 1997.

Ficino, Marsilio. Les Trois Livres de la Vie. Reimpressão da tradução francesa, por Guy Le Fèvre, de 1582. Paris: Fayard, 2000.

Genette, Gérard. L'Oeuvre de l'Art: Immanence et Transcendance. Paris: Seuil, 1994.

Gerard, Alexander. An Essay on Genius. Reimpressão da edição de 1774, por Bernhard Fabian. Munique: Wilhelm Fink Verlag, 1966.

Girons, Baldine Saint. Fiat Lux: Une Philosophie du Sublime. Paris: Quai Voltaire, 1993. 
Hartman, Charles O. Free Verse: An Essay on Prosody. Princeton: Princeton University Press, 1980.

Hartmann, Pierre. Du Sublime (De Boileau à Schiller). Estrasburgo: Presses Universitaires de Strasbourg, 1997.

Horácio. Arte Poética. Editado por R. M. Rosado Fernandes. Mem Martins: Inquérito, 2001.

Kant, Immanuel. Crítica da Faculdade do Juizo. Lisboa: Imprensa NacionalCasa da Moeda, 1998.

Kirk, G. S., J. E. Raven e M. Schofield. Os Filósofos Pré-Socráticos: História Crítica com Selecção de Textos. Lisboa: Fundação Calouste Gulbenkian, 1994.

Klibansky, Raymond, Erwin Panofsky e Fritz Saxl. Saturne et la Mélancolie: Études Historiques et Philosophiques: Nature, Religion, Médecine et Art. Paris: Gallimard, 1989.

Longino, Dionísio. Do Sublime. Editado por Marta Várzeas. Coimbra: Imprensa da Universidade de Coimbra, 2015.

Mendonça, José Tolentino. “A Solidão dos Filhos de Deus". A Phala 86 (2001): 55.

—. "Ruy Belo, Clandestino Seguidor de Deus". Introdução a Aquele Grande Rio Eufrates, por Ruy Belo. Lisboa: Presença, 1996.

Meschonnic, Henri. Politique du Rythme, Politique du Sujet. Paris: Verdier, 1995.

-. Critique du Rythme: Anthropologie Historique du Langage. Paris: Verdier, 2002.

Murray, Penelope, ed. Genius: The History of an Idea. Oxford: Blackwell, 1989. Paz, Octavio. El Arco y la Lira. México: Fondo de Cultura Economica, 1981.

Pigeaud, Jackie. La Maladie de l'Âme: Étude sur la Relation de l'Âme et du Corps dans la Tradition Médico-Philosophique Antique. Paris: Les Belles Lettres, 1989.

Ribeiro, Manuel António. A Margem da Transcendência: Um Estudo da Poesia de Ruy Belo. Lisboa: Fundação Calouste Gulbenkian, 2004. Edição de "Ruy Belo, Poeta Religioso". Dissertação de doutoramento, Universidade Católica Portuguesa, Lisboa, 2001.

—. "O Problema de Deus na Poesia de Ruy Belo". Communio 6 (2002): 509517.

Scheler, Max. Le Saint, le Génie, le Héros. Friburgo: Egloff, 1944.

Shaftesbury, Lord [Anthony Ashley Cooper]. Characteristicks of Men, Manners, Opinions, Times. Reimpressão da edição de 1711. Hildesheim: Georg Olms Verlag, 1978. 
Soares, Ana Maria Pereira. "A Alegria e o Mal em Ruy Belo: Estudo da Composição Hipertextual d'A Margem da Alegria". Dissertação de doutoramento, Universidade do Porto, 2017.

Vico, Giambattista. Principes d'une Science Nouvelle Relative à la Nature Commune des Nations. Editado por Alain Pons. Paris: Fayard, 2001.

Zilsel, Edgar. Le Génie: Histoire d'une Notion de l'Antiquité à la Renaissance. Paris: Minuit, 1993.

Luís Adriano Carlos

Departamento de Estudos Portugueses e Estudos Românicos

Faculdade de Letras

Universidade do Porto

Via Panorâmica, s/n 4150-564 Porto (Portugal)

http://orcid.org/0000-0001-8005-9886 